\title{
A Prelude to the Study of Indigenous, Pre-European, Church Architecture of Kerala
}

\author{
Sunil Edward
}

\begin{abstract}
Christianity is believed to have been first introduced to Kerala in $52 \mathrm{CE}$ through St. Thomas, the Apostle. This paper introduces the traditional indigenous Church architecture of Kerala that existed before the arrival of Portuguese in 1498 CE. The paper mainly looks into the circumstances under which it got destroyed and also analyses the reasons for its disappearance. The paper concludes that after the arrival of the Europeans and, in their initiative to bring the Kerala church closer to the Western church, they constituted a conscious attempt to alter the religious architecture of traditional Kerala Christians, declaring that it was Hindu by nature. Their intervention caused an irreparable break in the age-old system, and introduced a totally new and alien style to the traditional church building character, form and scale, forcing the traditional church architecture of centuries to be wiped off forever.
\end{abstract}

Keywords: Indigenous; Church Architecture; Kerala; Portuguese; Information Sources

\section{INTRODUCTION}

Calicut, 1498 AD: Vasco da Gama entered the entrance gateway of the Church complex and proceeded to the Church building. He was happy to go to the Church after the long and uncertain ship journey. Uncertain, as an explorer, going to a new land always had an uncertainty in it, but he loved it. It's the satisfaction one gets in reaching the destination, a new land, that counts. He liked this new land too, which his men called the 'Serra', Portuguese word for the mountain. Further, he was amazed to know there was already a Christian community living there, existing for centuries. The people were simple, half-naked, he would say. As he proceeded further into the church, deliberately ignoring the perplexed looks of the local people, which he was used to in every new land. He correctly assumed that some were angry, which he chose to ignore. Though he was happy to see Christians in the new land, he was already annoyed to see and hear about their curious customs, their dressing habits and their church buildings, all of which had been already reported to him. He entered the Church building and prayed. Suddenly he saw one of his own men come running towards him, and was informed, "Sir, this is a Hindu temple, not a Christian Church".

Whether this account is based on an actual incident, or is merely a fable, its narration is very popular in Kerala. If the incident indeed did take place, it also poses a curious question, "Why did it happen?" Gama was a well traveled man; he had seen a lot of churches. When one travels, for the first time, to a

Creative Space Vol. 1, No. 2 January 2014 pp. $167-177$

CHITKARA 司 C2014 by Chitkara University. All Rights Reserved. 
Edward, S.

new country, one wouldn't barge into any religious building thinking that it could be a Christian church, even when one knows that there were Christians in the new land. There is little or no possibility for mistaking a Hindu temple for a Christian church -- unless, of course, one has a preconceived and a fixed notion regarding the form and appearance of church buildings of the new land.

To understand possible reasons for the confusion, one has to travel back in time to the Fifteenth Century Kerala, and, try to look at the then existing church buildings of the region. But then, are there any church buildings of $15^{\text {th }}$ century which have been conserved today without any physical change, that is, without any architectural facelifts, extensions or modifications?

The answer, unfortunately, is in the negative. The question then is, whether there exist any other sources through which one can obtain authentic and accurate information about the content and form of the Fifteenth Century churches in Kerala?

In the absence of physical evidence, the quest began for written records of the era. Thanks to the many European pilgrims, travelers and writers of the Fifteenth, Sixteenth and Seventeenth Centuries, the original state of indigenous churches has been recorded in several documents. Scholarly and meticulous perusal of these historical records gives clues, if not definitive answers, for identifying possible reasons behind Gama's mistaking a Keralite Christian Church for a Hindu Temple.

\section{THE INDIGENOUS CHURCH ARCHITECTURE OF KERALA}

In general, all writers seem unanimous in their observation that the churches of the pre-Portugese Kerala resemble the "pagodas of the Hindu", the term 'pagoda' being used to described the traditional multi-tiered, pitched roofs of Kerala's temples. For example, Monserratte S.J., a Spanish priest who visited Kerala in 1579 CE, was to record that "Their (Christians of Kerala) Churches, of which there are still many, were built in the same manner as the houses of the idols of these parts; the present Archbishop sees to it that they are built in our style" (Athapilly, 2000, p.152). This statement attests three facts: one, that the churches that existed in $1579 \mathrm{CE}$ were not built in the manner that was familiar to the Europeans; two, that these churches were built in the same style, or appeared similar to the "houses of the idols", or the Hindu temples that then existed in Kerala; and, three, the attempt by the Europeans to change the architectural character and style of the then existing churches to what was familiar to them. This also gives an indication of the reason for the complete absence of such buildings today. 
The most prominent among the writers to have described Kerala's churches of the pre-Portuguese periods was Antonio de Gouvea, who accompanied Archbishop Dom Menezes, the Archbishop of Goa on his Kerala visit in 1599 CE. His monumental work 'Jornada do Arcebispo Dom Feri Alexis', was originally written in $1599 \mathrm{CE}$ in the Portuguese language and was first translated to English in 2003. Here again, Gouvea uses the term 'pagoda of the Hindus' to describe the appearnace of an indigenous Kerala church and explicitly writes that, "all the old ones (churches of Kerala) were built in the style of the temples of the gentiles" (Athapilly, p. 29). The buildings were "small" (Athapilly, p. 359), "so narrow and low, that scarcely was it possible to raise the Most Holy Sacrament at the altar" (Athapilly, p. 340) and "very dark" (Athapilly, p. 437) inside as there were no windows. He also mentions that the Kerala Christians had "made around (the church) ... a very high wall", which could be crossed only "with ladders" (Athapilly, p. 137-138) because of its height. This observation is also supported by many such compound walls that are still extant in many old Christian Churches and Hindu Temples of Kerala. He further adds that some churches, like the St. George Church, Aruvithura (Erattupetta) was "built of bamboo, like the temples of the gentiles" (Athapilly, p. 441-442), describing the architectural style that then existed. (Fig. 1)

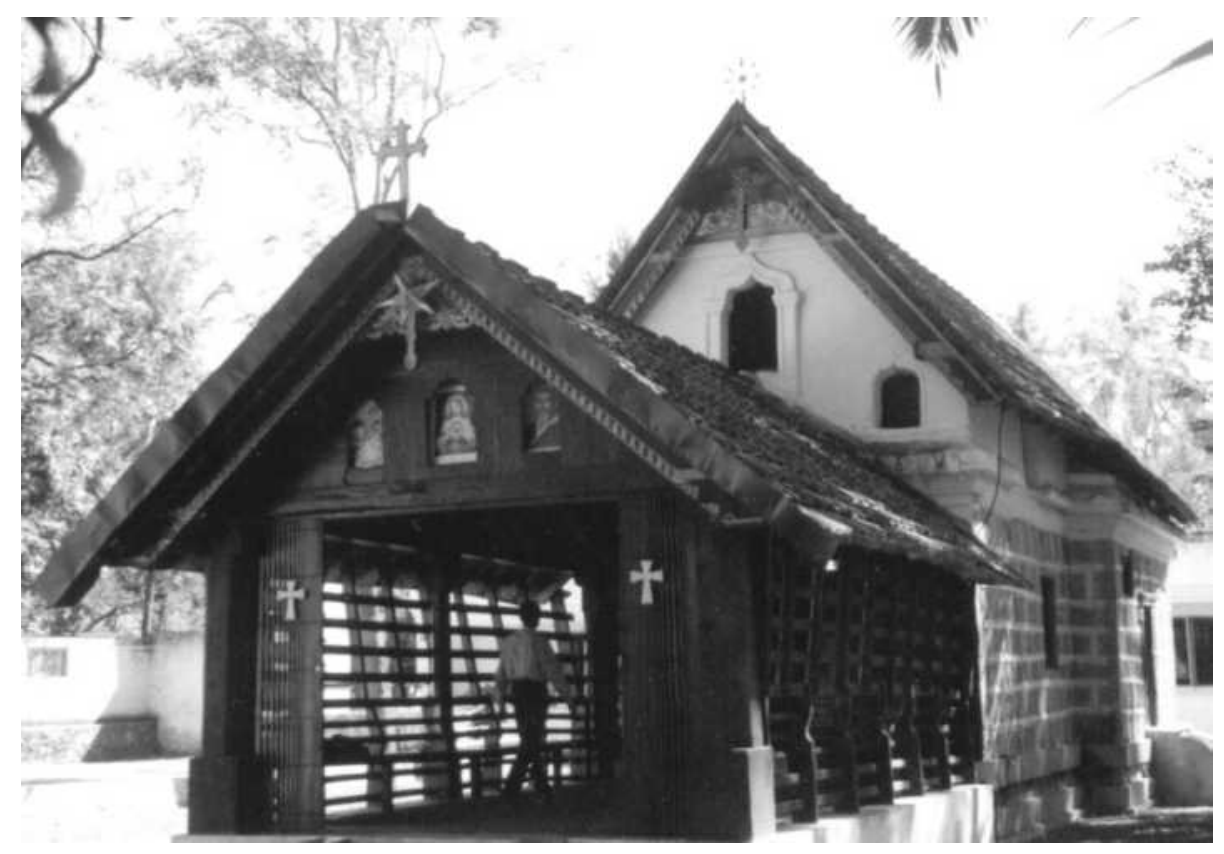

Figure 1: Bamboo and Timber construction in the existing Thiruvithamcode Church. (Image Source: Sunil Edward)
A Prelude To The Study Of Indigenous, Pre-European, Church Architecture Of Keralas

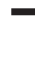


Edward, S.

In fact, the view that before the arrival of the Portuguese, the indigenous churches looked more like Hindu temples is a well known fact amongst most celebrated historians of Kerala ${ }^{1}$. In one of the publications by Kerala History Association, Nedumkunnam (1968) states, "to the viewer, the only difference between a temple and a Christian church (before the Portuguese period) could be only the cross in front. The form, shape and elements of a church were the same as that of a temple. This setup changed only after the arrival of the Portuguese"(Nedumkunnam, 1968, p. 161).

As a matter of fact, the official view of the Kerala Church Curia is also same. 'The Verapoly Archdiocesan Centenary Souvenir (1886-1986)', an official publication of the Catholic Archdiocese of Ernakulam states: "In middle ages the church construction took many things from temple style ... this existed before the arrival of the Portuguese and till the end of $16^{\text {th }}$ century" (Ochathuruthe, 1986, p.150). The Christian Encyclopedia (1972) also describes the Kerala church building before Portuguese period thus: "The worshipping places of the Christians looked like that of non-Christians except the crosses kept on the roof and in the front of the building"(Kraishava Vignana Kosham, 1972, p.72). Dr. Xavier Koodapuzha, a scholar in Kerala church history, has this to say about pre-Portuguese Kerala churches, "Churches looked like Hindu temples from outside ... The processions of the church also looked like that of Hindu temple. It was only from the Cross carried in front that it could be made out".

Another prominent architectural feature that distinguished the indigenous Kerala church from its European counterparts was the Mukha-mandapam (entrance porch) in the front (Fig. 2). Gouveia (1606) cites that on many occasions, that the Archbishop Menesis rested in the "porch of the church" (Gouveia and Malekandathil, 2003, p. 205, 208, 209), while Maria (1672) writes, "...on going to the church they (Christians) leave their guns or spears in the porch outside" (Maria, 1672, p. 151). Iyer (1926) quotes yet another seventeenth century European traveler who says, “...when they entered the church they deposited all their arms in the porch which then presented the appearance of a guard house". Further, contemporaneous descriptions of the existence of Mukha-mandapam are also supported by many such structures that are still in existence (Fig. 3).

The souvenirs published by many churches, in connection with their annual festival, usually contain a history of the church, and have also been referred to by the author. Many of these writings also indicate the fact that their church

1 Historians such as Nigam Aiya, Injackalodi, Koodapuzha, P. Thomas, A. Sreedhara Menon, Rawilson, N.K. Jose, George Menachery, Andrews Athapilly, J.J. Morris, J. Jacob, etc., have all mentioned this fact in their writings, both on Kerala history and Kerala Church history 


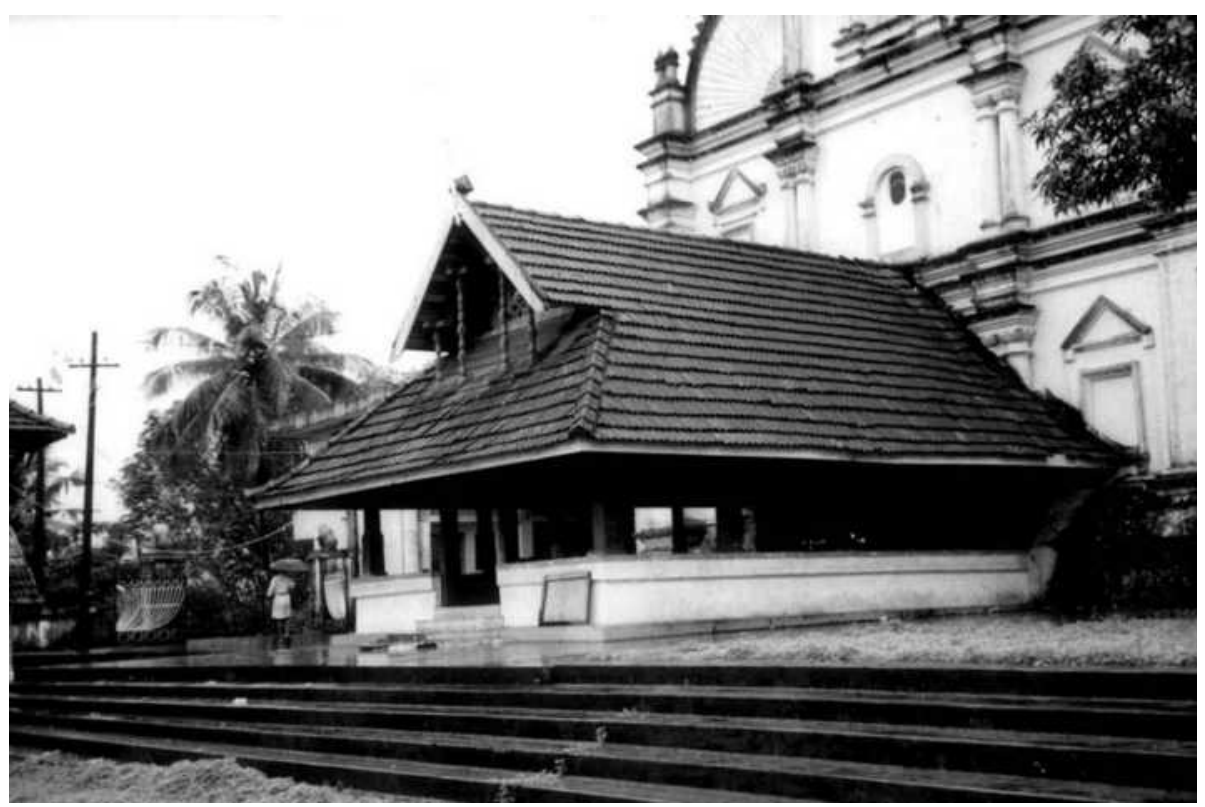

A Prelude To The Study Of Indigenous,

Pre-European, Church Architecture Of Keralas

Figure 2: Mukha-mandapam of existing Kadamattom Church. (Image Source: Sunil Edward)

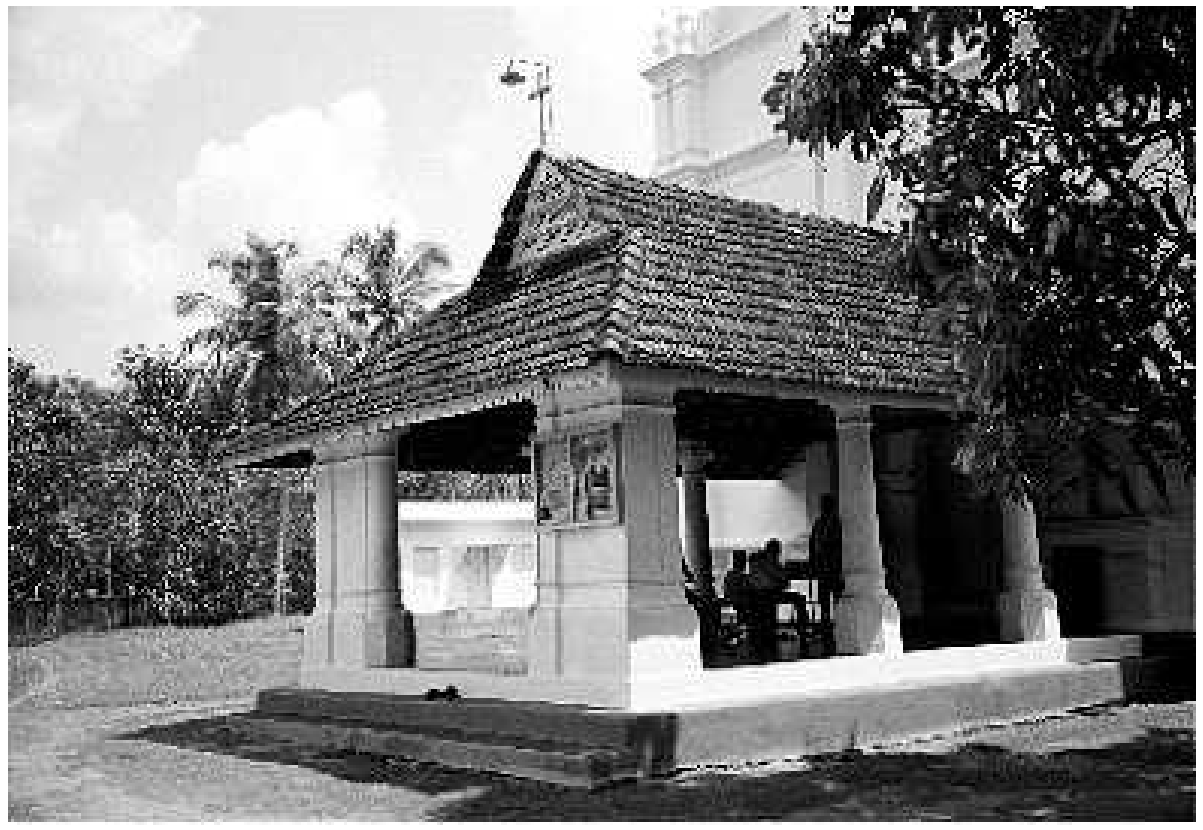

Figure 3: Mukha-mandapam, the existing Kanjoor Church. (Image Source: Sunil Edward) 
Edward, S.

building originally looked like a Hindu temple and was later demolished to build the newer church on European patterns. Such examples can be found in the souvenirs of the churches at Pala, Aruvithura, Kuravilangad, and Bharanamganam, among others. The Golden Jubilee Souvenir of the Diocese of Palai mentions, "The churches that were present in Kerala before the arrival of the Portuguese were built in stone or wood in the style of Hindu temples. It was only because of the cross present in the church that the foreigners could make out that it was a church". The author further states, "The churches built in the style of Hindu temples were rebuilt by the Portuguese in $16^{\text {th }}$ century in their style with massive walls in laterite and lime. Portuguese Franciscan priest Vincent De Logos headed this reconstruction activity".

This similarity between the Hindu and Christian places of worship is attested also by Archaeological Survey of India in its official publications. For example, Sarkar (1978), states that, “... Kerala (churches) adapted, by and large, a temple plan comprising a four-sided sanctuary fronted by a larger pillared hall which, in Christian tradition, became chancel and nave respectively" (Sarkar 1978, p. 45).

Other than the literary evidences, there is also some archaeological evidence to support this contention. There are many existing churches in Kerala, part of which was constructed before the imposition of Portuguese architectural style, and these churches clearly attest the existence of a pure indigenous Kerala church architectural style. Some examples are the churches of Kallooppaara (Fig. 4), Ambalpally at Kunnumkulam (Fig. 5), Thiruvitamcode, etc.

\section{DIFFERENCES IN THE INTERIORS}

The architectural dissimilarities of Kerala's pre-Portuguese churches, as compared to the European churches, were not restricted to the external appearance but could also be seen in the interiors of the churches.

One of the differences that has been recorded is that the original Kerala churches were devoid of any imagery or statues inside the church before the arrival of the Europeans. Fr. Alvaro Penteado wrote to the king of Portugal in 1517-19, "They (Kerala Christians) have crosses in their churches on the altars as well as engravings, but no images or engraved outlines of profiles and faces" (Mundadan, 1970, p.158). Gouveia also states that the Archbishop Menezes did not "find in the church anything more than a cross" (Gouveia and Malekandathil, 2003, p. 404). In fact, a decree of the Synod of Diamper, ${ }^{2}$ held at Udayamperoor in1599 (Action VIII, Decree XXIX) deplores the mean

2 Synod of Diamper, held on 20 June 1599 at Udayamperoor (Daimper), formally united the ancient Saint Thomas Christians of Kerala with the Roman actholic Church 


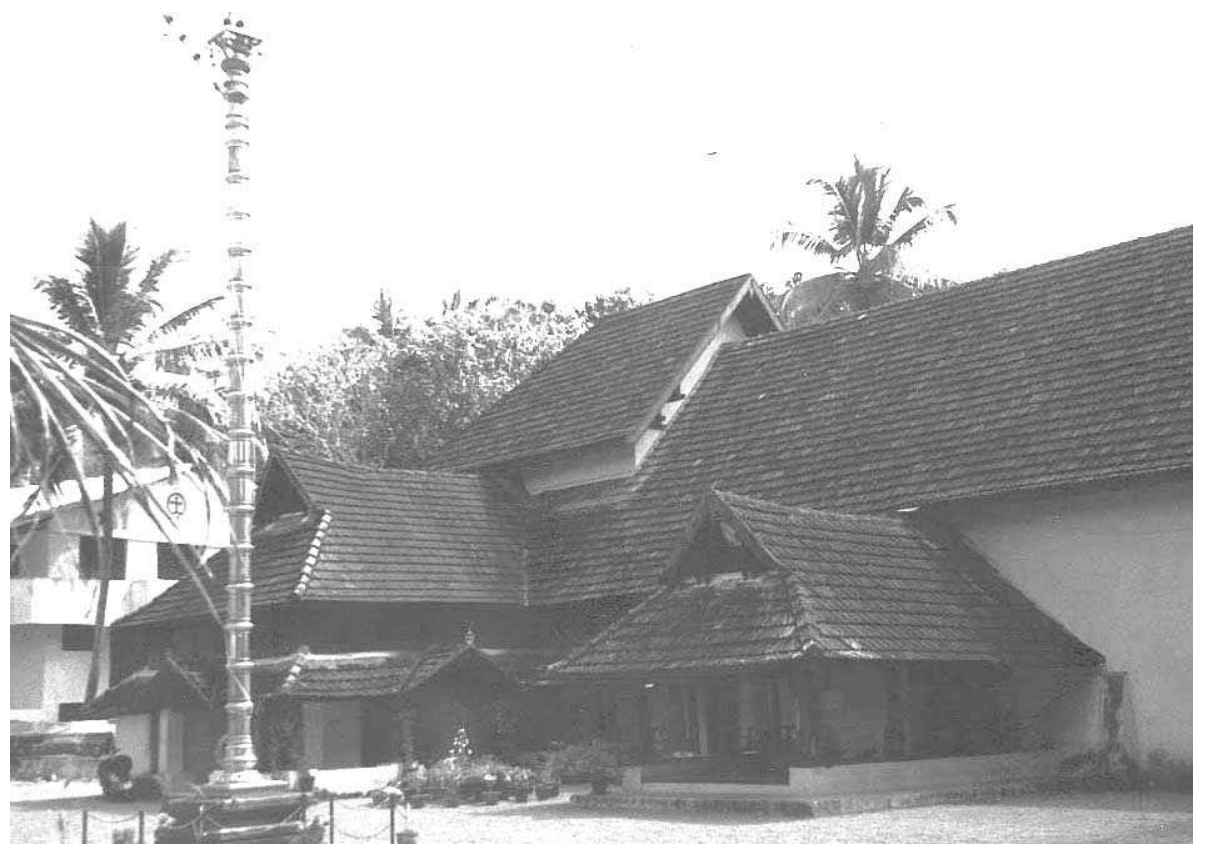

A Prelude To The Study Of Indigenous, Pre-European, Church Architecture Of Keralas

Figure 4: The existing Kallooppaara Church. (Image Source: Sunil Edward)

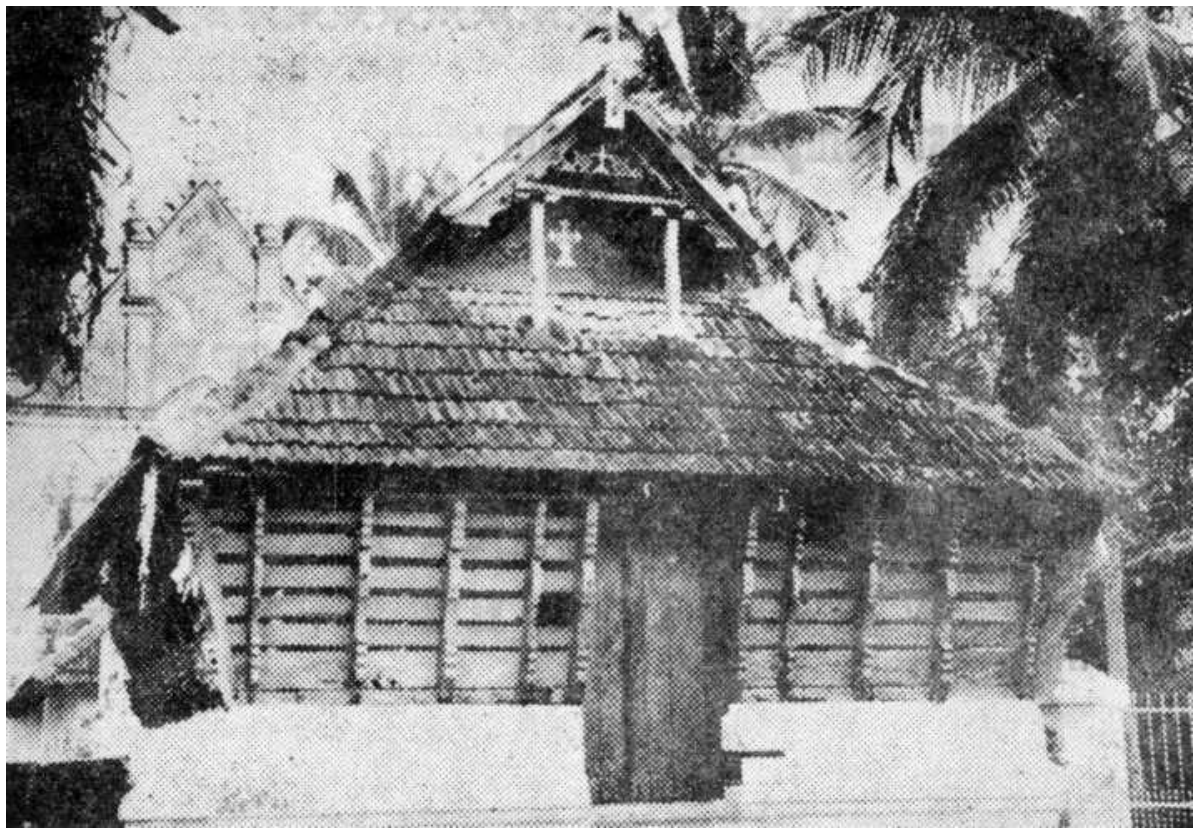

Figure 5: The church at Ambala-palli, Kunnumkulam. The original church is partially demolished.(image Source: Unknown) 
Edward, S.

look of the interior of Kerala churches saying, “....almost all of the Churches of this Diocese are without pictures" and further orders that all churches "shall be to set up some images" (Geddes, 1694-1998, p.94). Gouveia further states, "He (Archbishop Menezes) provided (the Kerala Christians) with pictures and images, (...) because none of these things were there in the churches of $\operatorname{Serra}^{3}(\ldots)$ because in olden times (it) was accepted among Christians, the error against the holy images" (Gouveia and Malekandathil, 2003, p. 454). Athapilly (2000) says, "The Portuguese noticed the reason for this (is) that, St. Thomas had forbidden the use of statues" (Athapilly , 2000, p. 152).

Both these facts (that is, the absence of images in Churches and forbiddance of use of imagery) were also acknowledged by European writers some 150 years before Gama's arrival in Kerala. It was first written about in $1348 \mathrm{CE}$ by Friar John De Marigoli who, during his stay at Kollam in 1346 CE, celebrated mass in St. George Church in Kollam ${ }^{4}$. Fr. Marigoli writes that "there were no pictures inside that church", and further adds that "some of the Christians regarded the Latins (meaning the European Christians) as worst of idolaters because they (Latins) used statues in their churches" (Moraes, 1964, p. 104). Therefore, it can be well concluded that the early Kerala churches had used symbols inside their churches for veneration, unlike paintings or statues of Jesus Christ, Mother Mary or any saints used in their European counterparts.

\section{TRANSFORMATIONS BY THE PORTUGUESE}

As regards the transformation of the indigenous church to a European model, the major source of information is the verifiable set of notes written by Fr. Vincent, the builder of St. Mary's Church at Puthanchira. These notes reveal the "introduction" of a new architectural style, and the suppression of the indigenous Kerala church architecture. Fr. Vincent states that he had "extensively traveled from 1530 to 1545 and introduced Gothic style in many churches of Kerala", the term "introduced" implying also the complete replacement of the indigenous 'style' to the Gothic Style then favoured for churches in Europe.

One of the main feature of any European church was its imposing front façade, whereas the indigenous Kerala churches did not have such a feature at all. The 'front wall' was plain, with a tile and wood roof projecting over that it. After the arrival of Portuguese, this wall (usually the western wall)

3 Portuguese word meaning 'mountains', used for the Malabar hills of Kerala

4 This church was constructed by Friar Jordanus Cattalaani between 1320 and 1330, but it was destroyed by sea, thus again leaving no clue on what the building looked like.

5 Manjali, Rev. Dr. Antony, $16^{\text {th }}$ Shadabthi Smaranika St. Mary's Forane Church, Puthenchira, Puthenchira: St.Mary's Church.. 
was built much higher than the nave roof, and decorations were added to it. Richards (1908) observes this change and writes, "The western wall of Kerala church in modern days is adorned with plastered pillars and pinnacles, after the Portuguese fashion".

To conclude, all these above-referred literary and other sources attest the fact that the pre-Portuguese, indigenous churches of Kerala had an altogether regional, native appearance before the arrival of the Portuguese, who then were largely responsible for the drastic transformation of the Kerala church to something totally alien.

\section{ANOMALIES IN LITERARY SOURCES}

The study of literary sources has also revealed some anomalies in the perceived association between the earliest Hindu and Christian houses of worship in Kerala. For example, in a publication on Kerala temples by the Archaeological Survey of India, the study on the beginning of structural temples of Kerala concludes that "... thus the inscriptional evidence suggests that the temple architecture must have had its beginning at least by early part of ninth century" (Sarkar, 1978, p. 27). Later, in the same book, the author mentions that "Kerala had some churches in sixth century as is testified by Cosmos Indicopleustes" (Sarkar, 1978, p. 44). And, yet, the chapter on church architecture states that "on the other hand, Kerala (churches) adapted, by and large, a temple plan comprising a four-sided sanctuary fronted by a larger pillared hall which, in Christian tradition, became chancel and nave respectively" (Sarkar, p. 45).

Is it being argued that the church buildings which existed at least from $6^{\text {th }}$ century, "adopted" the temple plan, which as per author's own argument, "had its beginning ... by the early part of ninth century". Similar contradictions can also be seen in many other historical and architectural writings. A possible, and credible, reason for this state could be that the Hindu temples which existed much earlier than ninth century, being made of perishable materials, do not exist today and the indigenous Church Architecture of Kerala is not yet understood fully.

\section{CONCLUSIVE REMARKS}

This paper only opens a prelude to a sorely lacking and a much needed study. However, when one studies the indigenous Kerala Church, it is clear that the older buildings of different religions in Kerala were always conceived as a part of a comprehensive fabric, and never as isolated structures with deliberately different architectural typologies and meanings. It seems that achieving a homogeneous regional identity between buildings for spiritual purposes was
A Prelude To

The Study Of

Indigenous,

Pre-European,

Church

Architecture Of

Keralas

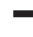


Edward, S.

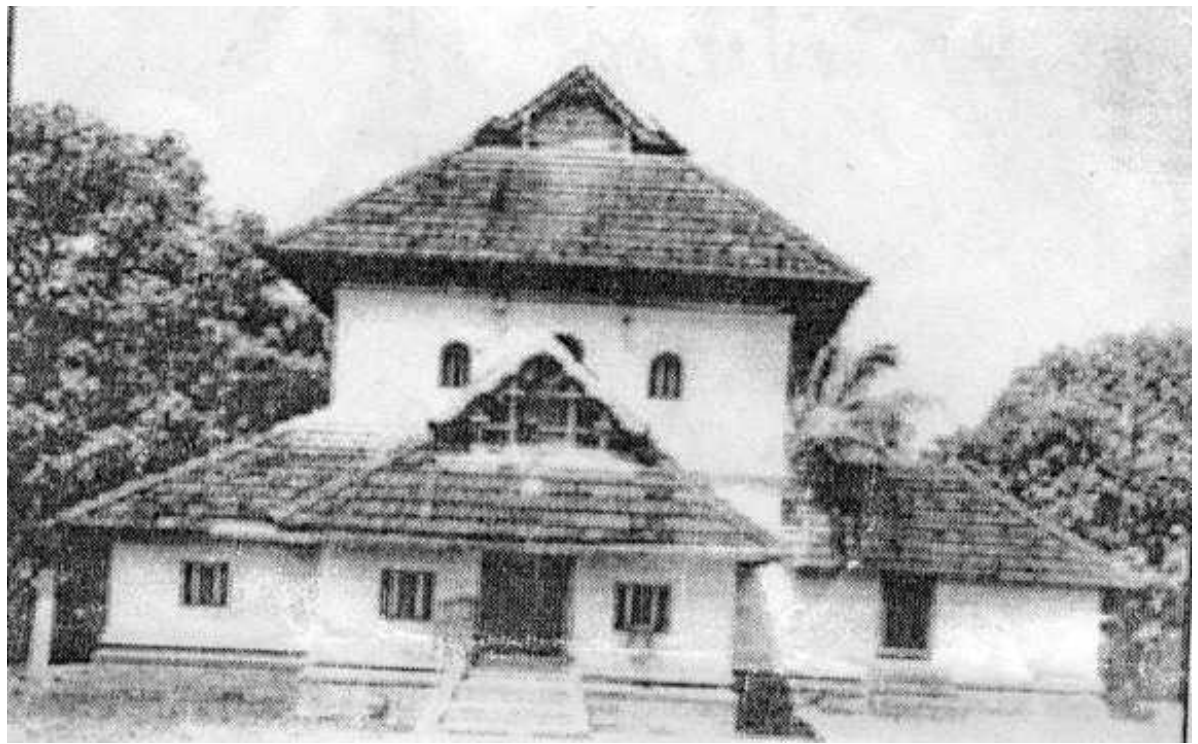

Figure 6: A 1905 photograph of the Cheraman Juma Masjid in Methula, Kodungallur Taluk, Kerala, said to the very first mosque in India built in 629 CE. (Image Source: http://www. islamicvoice.com/june 2004/images/Masjid-1.gif. Accessed on 22.01.2014)

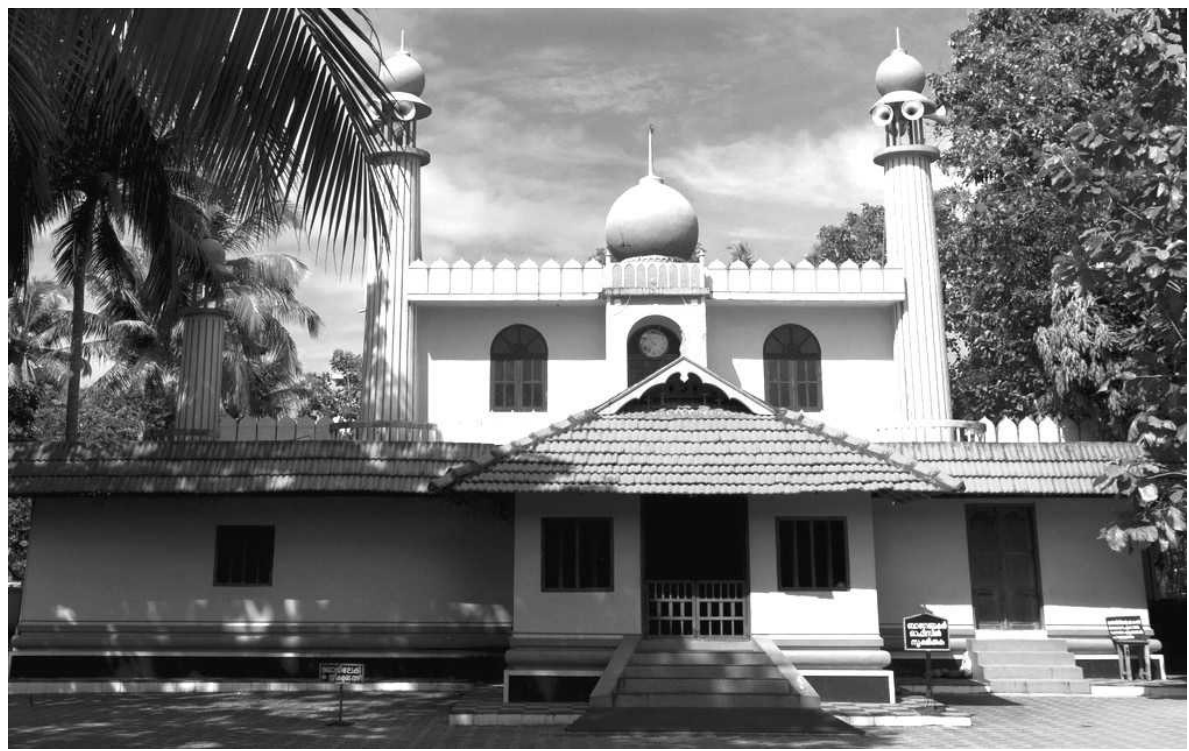

Figure 8: Photograph of the Cheraman Juma Masjid in 2012. (Based on Image Source: upload.wikimedia.org. Attribution: User: shahinmusthafa. Accessed on 22.01.2014) 
the norm of the past in Kerala and the line of demarcation between Hindu, Muslim, Christian, Jain or Buddhist edifices was imperceptible.

This fact will become very evident as one investigates and compares older religious structures with those built in today's context. For example, many a typical feature of today's mosques, such as minars and domes, were totally absent in older periods. There still exist in Kerala a few older mosques which were built in total conformity of the traditional Kerala architectural style (Fig. $6 \&$ 7). Similarly, the façade of the older churches that one visualizes is very different from that which is popular today, and which was imported only after Sixteenth Century with the advent of the Portuguese.

After the arrival of the Europeans and in their initiative to bring the Kerala church closer to its Western counterpart, this traditional fabric was disrupted, and the sense of wholeness and parallelism among religions vanished, as did the physical coherence of religious buildings to the natural environment. The Europeans altogether constituted a concerted attempt to alter the religious architecture of traditional Malabar Christians, declaring that it was Hindu by nature. Their intervention caused an irreparable break in the system, and introduced a totally new and alien character, form and scale to the traditional church building, forcing the conventions of centuries to be wiped off forever.

\section{REFERENCES}

ATHAPILLY, ANDREWS. (2000) Kerala Church Architecture, In Menachery, George (ed.). The Thomapedia. Ollur,Kerala: Thomapedia

GEDDES, MICHAEL. (1694). A Short History of the Church of Malabar together with The Synod of Diamper. London: Sam, Smith, and Benj. Walford. (Reprinted MENACHERY, GEORGE (ed.) in Indian Church History Classics, The Nazaranies. Trissur, Kerala: SARAS)

IYER, L.K.ANANTHAKRISHNA (1926) Anthropology of the Syrian Christians. Ernakulam, Kerala:??

GOUVEIA, ANTONIO DE and MALEKANDATHIL, PIUS. (2003) Jornada of Dom Alexis De Menezes: a Portuguese account of sixteenth century Malabar. Kochi: LRC Publications.

MARIA, VINCENZO. (1672) Il Viaggio all'Indie Orientali. Rome: Filippomaria Mancini.

MORAES, GEORGE MARK. (1964) A History of Christianity in India. Bombay: Manaktalas

MUNDADAN, A. MATHIAS. (1970) Sixteenth Century Traditions of St. Thomas Christians. Banagalore: Dharmaram College.

NEDUMKUNNAM, JOSEPH. M. O. (1968) History on the March. Ernakulam: Kerala History Assossiation.

OCHATHURUTHE, JOHN. (1986) Nammude Pallikalude Vaasthuvidya Parambaryam (Malayalam),. In VELIPARAMBIL, GEORGE (ed.). The Verapoly Archdiocesan Centenary Souvenir (1886-1986). Ernakulam: Verapoly Archdiocese.

RICHARDS, W.J. (1908) The Indian Christians of St. Thomas. London: London \& Derby.

SARKAR, H. (1978) Monuments of Kerala. New Delhi: Archaeological Survey of India.
A Prelude To

The Study Of

Indigenous,

Pre-European,

Church

Architecture Of

Keralas 